\title{
Recurrent Aseptic Meningitis Secondary to Intracranial Epidermoids
}

\author{
Werner J. Becker, Gordon V. Watters, Jean-Pierre de Chadarevian and Michel Vanasse
}

\begin{abstract}
Two patients with recurrent aseptic meningitis are reported. Intracranial epidermoid tumors were eventually found in both patients. CSF changes in our first case with an epidermoid tumor were similar to those reported in Mollaret's meningitis, with an initial polymorphonuclear pleocytosis early in each attack, followed by a lymphocytic predominance several days later. Large cells which proved to be macrophages were also seen in the CSF of this patient. Both patients had meningitis attacks for several years before the underlying epidermoid tumor was found. Mollaret's meningitis remains a diagnosis of exclusion. These patients should remain tumor suspects for many years and deserve careful and repeated investigation.
\end{abstract}

RÉSUMÉ: Nous rapportons la méningite aseptique chez deux patients. Des tumeurs épidermoïdes intracrâniennes ont été eventuellement trouvées dans ces deux cas. Des changements dans le LCR dans notre premier cas associés d'une tumeur épidermoide étaient pareils a ceux décrits dans la méningite de Mollaret, avec une pleocytose polymorphonucléaire qui c'est produit tôt dans la crise, suivi par une prédominance lymphocytaire plusieurs jours plus tard. Aussi trouvé dans le LCR de ce patient sont des grossescellules qui étaient en veriteaz des macrophages. Ces deux patients souffrirent des crises méningite depuis plusieurs années avant la découverte de la tumeur épidermoïde. La méingite de Mollaret reste toujours une diagnose d'éxclusion. Ces patients devraient rester soupçonnés d'avoir des tumeurs pendant plusieurs années et méritent des enquetes soigneusement répéter à plusieurs occasions.

Can.J. Neurol. Sci. 1984; 11:387.389

Recurrent aseptic meningitis is an uncommon clinical syndrome with many possible etiologies. Included among these are intracranial and intraspinal epidermoid tumors. We present here two children with multiple attacks of aseptic meningitis over many years who eventually proved to have intracranial epidermoid cysts.

Case 1: A six year old girl presented in June 1976 with vomiting, fever, headache, meningismus, and lethargy. Her temperature was $38.2^{\circ} \mathrm{C}$. Spinal fluid showed a leukocytic pleocytosis, and antibiotics were started. Forty-eight hours after admission she was afebrile and without neck stiffness. All bacterial, fungal, and viral cultures were negative.

Over the next three and a half years she had approximately twenty one further attacks of meningitis, most of which were similar to her initial attack. During an attack, her CSF (Table 1) showed an initial response of 1000 to 5000 polymorphonuclear leukocytes per $\mathrm{mm}^{3}$, and an elevated protein content. CSF glucose values were low in many of her attacks. Several days after onset, mononuclear cells would predominate in the CSF (Table 2), Most of her attacks were followed by spontaneous recovery within $\mathbf{4 8}$ hours, and antibiotics were given only for her first two attacks. Nine months after her first admission, she had her ninth and most severe attack. This was her only attack of meningitis which was complicated by abnormal neurological signs.

Headache and meningismus on this occasion were followed by diplopia, left ptosis, bilateral abducens nerve palsies, bilateral facial nerve palsies, and bilateral blurring of optic disc margins. CSF opening pressure was $560 \mathrm{~mm}$ CSF. A pneumoencephaloam gave no evidence for an intracranial mass lesion. She gradually improved, and by the 19th day was well. Repeat lumbar puncture showed an opening pressure of $120 \mathrm{~mm} \mathrm{CSF}$.

Until January 1980, she remained well between attacks, and growth and development were normal. Numerous investigations including two brain computed tomographic (CT) scans, isotope brain scan, gallium bone scan, diphosphate and gallium radioisotope brain scans, complete spinal myelography, and cisternography using ${ }^{169}$ ytterbium were normal. Numerous CSF cultures, India ink preparations, and CSF searches for keratin and cholesterol crystals were normal. CSF IgG levels never exceeded ten percent of the total CSF protein.

In January 1980 she was re-admitted with severe headache. Her neurological examination was normal, but brain CT scanning showed a cystic lesion in the left posterior fossa with displacement of the 4th ventricle, but without hydrocephalus. A posterior fossa craniectomy showed a thin translucent cyst with chalky granular nodules. The cyst contained $40 \mathrm{ml}$ of off-white, low viscosity fluid. It occupied the left side of the posterior fossa floor, and the lower cranial nerves were bound by fibrous scarring as they passed over the roof of the cyst. The cyst was drained and incompletely excised. A brain CT scan three weeks later showed no residual mass and the fourth ventricle was normal in position.

She did well until August 1980, when another attack of meningitis occurred. Her CSF showed over 6000 white cells, mostly polymorphonuclears, a low glucose and elevated protein. A CT scan showed reaccumulation in the cyst. She remained disabled by recurrent attacks of meningitis, and in January, 1981, a second posterior fossa exploration was done. No accumulation of fluid within the cyst membrane was found, but attempts to remove the cyst membrane were only partially successful because of adherence to the cranial nerves. Post-operatively a left abducens nerve palsy was present and there was decreased hearing in the left ear. In February 1981 she was given 5000 rads of radiotherapy to the posterior fossa. A CT scan in 1981 showed no evidence of tumor recurrence, and her ventricles were normal. She remained free of attacks for the remainder of our followup period (until June 1982).

Case 2: A girl had recurrent febrile episodes beginning at four months of age. From three years of age, until her death at age five, she was followed at Hopital Sainte-Justine in Montreal. She had repeated attacks

From the The Montréal Childrens' Hospital, Montréal. Hôpital Sainte-Justine, Montréal

Received February 2, 1984. Accepted May 23, 1984.

Reprint requests to: Werner J. Becker, M.D., Calgary General Hospital, Room M3-O16, 841 Centre Avenue East, Calgary, Alberta T2E 0A1 
Table 1: Case 1 - CSF findings on first Day of Attacks

\begin{tabular}{lccccccccc}
\hline Date & $\begin{array}{c}\text { JUN } \\
\mathbf{7 6}\end{array}$ & $\begin{array}{c}\text { AUG } \\
\mathbf{7 6}\end{array}$ & $\begin{array}{c}\text { OCT } \\
\mathbf{7 6}\end{array}$ & $\begin{array}{c}\text { NOV } \\
\mathbf{7 6}\end{array}$ & $\begin{array}{c}\text { DEC } \\
\mathbf{7 6}\end{array}$ & $\begin{array}{c}\text { MAR } \\
\mathbf{7 7}\end{array}$ & $\begin{array}{c}\text { JUL } \\
\mathbf{7 7}\end{array}$ & $\begin{array}{c}\text { AUG } \\
\mathbf{7 7}\end{array}$ \\
\hline $\begin{array}{l}\text { Protein } \\
\text { g/L }\end{array}$ & 1.33 & 0.92 & 0.85 & 1.15 & 1.11 & 0.87 & 1.70 & 5.03 \\
$\begin{array}{l}\text { Glucose } \\
\text { mmol/L }\end{array}$ & 0.7 & 2.2 & 2.4 & 2.3 & 2.7 & 0.8 & 1.4 & 0.3 \\
$\begin{array}{l}\text { Mono- } \\
\text { nuclear } \\
\text { cells/mm }\end{array}$ & 268 & 814 & 170 & 576 & 250 & 620 & 312 & 12,000 \\
& & & & & & & & \\
no diff.
\end{tabular}

Blood glucose range $3.9 \cdot 7.8$

of headache, fever, and vomiting. Examination at these times showed a stiff neck, and frequently revealed a right 6 th nerve palsy and a mild left facial paresis, as well as at times, a mild left hemiparesis.

She had at least 15 attacks of varying severity. CSF cell counts ranged as high as 2700 cells $/ \mathrm{mm}^{3}$, usually with marked polymorphonuclear predominance, but occasionally with lymphocytic predominance. CSF protein ranged from 0.45 to $1.65 \mathrm{mmo} 1 / \mathrm{l}$ and CSF glucose from 1.7 to $4.5 \mathrm{mmol} / \mathrm{l}$. Multiple CSF cultures were negative except for one occasion when streptoccus viridans was grown from the CSF. Cholesterol crystals in her CSF were looked for, but not found. Multiple investigations including skull $x$-rays, EEG, carotid angiography, and repeated pneuencephalography were considered negative until 1969, at four years of age, when a right cerebellopontine angle lesion was suspected. At surgery, a dermoid cyst was found and partially removed from the right cerebellopontine angle.

Four days following discharge, she was readmitted with a further attack of meningitis. All cultures were sterile, but at surgical exploration several months later, an encapsulated abscess was found in the region of the dermoid cyst. Following surgery, she was well for three months, but then again had many attacks of meningitis. She died at five years, five months of age. Autopsy showed a right cerebellopontine angle dermoid cyst, and a pus-containing abscess at the superior pole of the cyst.

\section{DISCUSSION}

Many etiologies can give rise to recurrent aseptic meningitis. Recurrent viral meningitis is rare. Among 1956 cases of viral meningitis, Nadao and Miura (1971) found only four patients with three attacks or more. Other reported causes for recurrent aseptic meningitis include glioblastoma multiforme (Bernat, 1976), systemic lupus erythematosus (Finelle et al., 1976; Welsby and Smith, 1977), Behcet's Disease (Schotland et al., 1967), and intracranial hydatid cysts (Feld et al., 1955). Recurrent aseptic meningitis has also been reported in patients with intracranial epidermoid tumors (Leal and Miles, 1978), craniopharyngiomas (De Klerk and Spence, 1974; Ross, Russell and Pennybacker, 1961), spinal epidermoid tumors (Cantu and Wright, 1968), and spinal teratomas (Labrisseau et al., 1980). These tumors usually cause no more than two or three episodes of chemical meningitis, but Schwartz and Balentine (1978) reported a fourteen year old girl with an epidermoid cyst in the ventral pons who had ten episodes of meningitis over an eighteen month period. An arteriogram, pneumoencephalogram, ventriculogram, and myelogram failed to show the tumor, and it was discovered only at autopsy. After the above causes have been
Table 2: Case 2 - Serial CSF Results - Two Attacks

\begin{tabular}{lrrrrrr}
\hline $\begin{array}{l}\text { Day After } \\
\text { Attack } \\
\text { Onset }\end{array}$ & 1 & $\mathbf{4}$ & $\mathbf{1 6}$ & $\mathbf{1}$ & $\mathbf{2}$ & $\mathbf{8}$ \\
\hline $\begin{array}{l}\text { Protein } \\
\text { g/L }\end{array}$ & 0.92 & 0.34 & 0.42 & 0.85 & 0.35 & 0.40 \\
$\begin{array}{l}\text { Glucose } \\
\text { mmol/L }\end{array}$ & 2.2 & 1.7 & 2.2 & 2.4 & 2.5 & 2.3 \\
$\begin{array}{l}\text { Mono- } \\
\text { nuclear } \\
\text { cells } / \mathrm{mm}^{3}\end{array}$ & 814 & 161 & 13 & 170 & 169 & 26 \\
$\begin{array}{l}\text { Polys } / \mathrm{mm}^{3} \\
4074\end{array}$ & 56 & 6 & 1942 & 721 & 2 \\
\hline & & & & & & \\
\hline
\end{tabular}

excluded, there remain a group of patients in the literature with unexplained recurrent aseptic meningitis rarely accompanied by permanent central nervous system deficit. Eventually, the attacks of meningitis are said to cease spontaneously in most of these patients. Mollaret first described this syndrome in 1944 (Bruyn et al., 1962) and several reviews on this syndrome known as Mollaret's meningitis have been published (Mollaret, 1977; Hermans et al., 1972). Although initially reported in the French literature, a number of cases of Mollaret's meningitis have been reported from North America (Coleman et al., 1975; Galdi, 1979; Haynes et al., 1976; Mora and Gimeno, 1980; Saint Martin et al., 1982; Steel et al., 1982; Swithinbank and Rake, 1978) and continued to be reported (Tyler and Adler, 1983; Stamm et al., in press).

Our two patients confirm that intracranial epidermoid tumors may give rise to a very large number of recurrent attacks of chemical meningitis occurring over many years. Our first case had over twenty one attacks in a three and a half year period. During this time, the causative epidermoid cyst may remain small, possibly because the cyst contents are recurrently rupturing into the CSF, and the tumor may give rise to no focal neurologic signs during this period. Although looked for, keratin and cholesterol crystals could not be demonstrated in the CSF of our two patients. Inability to demonstrate keratin and cholesterol crystals in the CSF therefore does not rule out chemical meningitis from an epidermoid.

How many cases reported as Mollaret's meningitis in the literature were in fact related to epidermoid cysts or similar lesions is unknown, but the differential diagnosis can be a very difficult one. Case 1 in our series was considered to have Mollaret's meningitis for several years because all investigations for a structural intracranial lesion were negative. This diagnosis eventually proved to be incorrect. The CSF examination, aside from demonstrating keratin or cholesterol crystals, may not be helpful in differentiating Mollaret's meningitis from chemical meningitis secondary to an epidermoid cyst. In Mollaret's meningitis, the CSF is said to show several thousand polymoronuclears per $\mathrm{mm}^{3}$ initially, followed in several days by a predominantly lymphocytic pleocytosis (Hermans et al., 1972). This pattern of CSF abnormality was seen repeatedly in our Case 1 with an epidermoid tumor, indicating that the above CSF response is not specific for Mollaret's meningitis. During 
attacks of Mollaret's meningitis, a large cell of uncertain origin has also been noted in the CSF. These cells appear early in the attack, lyse quickly and are rare after the first day (Hermans et al., 1972) but may persist for fifteen days (Guran et al., 1977). In an ultra-structural study, these cells were designated as monocytes (Gledhill et al., 1975). Our Case 1 with an epidermoid tumor also had large abnormal cells in her CSF during the first 48 hours of her attacks, and ultra-structural studies showed these cells be to macrophages (de Chadarevian and Becker, 1980). These cells from our patient with chemical meningitis would appear similar to those described in some patients with Mollaret's meningitis (Haynes et al., 1976).

Mollaret's meningitis must therefore remain a diagnosis of exclusion. Patients with recurring aseptic meningitis of unknown etiology need repeated radiological attempts to demonstrate an underlying epidermoid cyst. The demonstration of these may be difficult, even with modern CT scan equipment, possibly because in these patients the cyst ruptures its contents into the CSF frequently, and therefore remains relatively small. These patients must remain tumor suspects for at least several years after onset of meningitis attacks. Unfortunately, as in both our cases, attacks of chemical meningitis may continue if the epidermoid cyst membranes cannot be removed completely. Steroids may be helpful in reducing the severity of meningitis attacks secondary to ruptured epidermoid tumor (De Klerk and Spence, 1974).

\section{ACKNOWLEDGEMENTS}

We thank Dr. Robert Hollenberg for his assistance.

\section{REFERENCES}

Bernat, JL (1976) Glioblastoma multiforme and the meningeal syndrome. Neurology 26: 1071-1074.

Bruyn GW, Straathof LJA, Raymakers GMJ (1962) Mollaret's meningitis: differential diagnosis and diagnostic pitfalls. Neurology 12: 745-53.

Cantu RC, Wright RL, (1968) Aseptic meningitic syndrome with cauda equina epidermoid tumor. J Pediatr 73: 114-116.

Coleman WS, Lischner HW, Grover WD (1975) Recurrent aseptic meningitis without sequelae. J Pediatr 87: 89-91. de Chadarevian JP, Becker WJ (1980) Mollaret's recurrent aseptic meningitis: relationship to epidermoid cysts. J Neuropathol Exp Neurol 39: 661-669.

De Klerk DJ, Spence J (1974) Chemical meningitis with intracranial tumors. S Afr Med J 48: 131-135.

Feld M, Brumpt L, Chambon M et al. (1955) Kyste hydatique autochtone parieto-occipital gauche, annoncé par une méningite lymphocytaire à réchutes. Ablation, guerison. Rev Neurol (Paris) 92: 297-300.

Finelle PF, Yockey CC, Hebert AJ (1976) Recurrent aseptic meningitis in an elderly man. JAMA 235: 1142-1143.

Galdi AP (1979) Benign recurrent aseptic meningitis (Mollaret's meningitis). Case report and clinical review. Arch Neurol 36: 657-658.

Gledhill RF, Lewis PD, Marsden CD et al. (1975) Is Mollaret's meningitis another periodic disorder responsive to colchicine? Lancet 2: 415.

Guran P, Beal G, Browaeys J, et al. (1977) Meningite multirecurrente benigne. Rev Neurol (Paris) 133: 245-254.

Haynes BF, Wright R, McCracken JP (1976) Mollaret's meningitis: A report of three cases. JAMA 236: 1967-1969.

Hermans PE, Goldstein NP, Wellman WE (1972) Mollaret's meningitis and differential diagnosis of recurrent meningitis. Am J Med 52: 128-140.

Labrisseau A, Renevey F, Brochu P, et al. (1980) Recurrent chemical meningitis due to an intraspinal cystic teratoma. J Neurosurg 52: 715-717.

Leal O, Miles J (1978) Epidermoid cyst in the brainstem. J Neurosurg 48: 811-813.

Mollaret P (1977) La méningite endothélio (?) - Leucocytaire multirecurrente benigne. Rev Neurol (Paris) 133: 225-242.

Mora JS, Gimeno A (1980) Mollaret's meningitis: report of a case with recovery after colchicine. Ann Neurol 8: 631-633.

Nadao T, Miura R (1971) Recurrent virus meningitis. Pediatr 47: 773-776.

Ross Russell, RW, Pennybacker JB (1961) Craniopharyngioma in the elderly. J Neurosurg Psychiat 24: 1-13.

Saint-Martin M, Duplantis F, Laverdiere M et al. (1982) Le Meningite de Mollaret. Can J Neurol Sci 9: 41-43.

Schotland DL, Wolf SM, White HH et al. (1967) Neurologic aspects of Behcet's disease. Am J Med 43: 227-253.

Schwartz JF, Balentine JD (1978) Recurrent meningitis due to an intracranial epidermoid. Neurology 28: 124-129.

Stamm AM, Livingston WK, Cobbs CG et al. (1984) Failure of colchicine in the treatment of Mollaret's meningitis. Arch Intern Med (in press).

Steel JG, Dix RD, Baringer JR (1982) Isolation of Herpes simplex virus type 1 in recurrent (Mollaret) meningitis. Ann Neurol 11: 17-21.

Swithinbank IM, Rake MO (1978) A case of Mollaret's meningitis associated with lymphoma. Postgrad Med J 54: 682-685.

Tyler KL, Adler D (1983) Twenty-eight years of benign recurring Mollaret meningitis. Arch Neurol 40: 42-43.

Welsby P, Smith C (1977) Recurrent sterile meningitis as a manifestation of systemic lupus erythematosus. Scand J Infec Dis 9: 149-150. 